Матеріали Всеукраїнської науково-практичної конференчії «Актуальні питання діагностики, лікування, раціональної фармакотерапії, диспансеризації та реабілітації в практиці сімейного лікаря" удК 616.12-008.331.1-06:616.379-008.65]-085.036.8

$\mathrm{DOI}$

\title{
ЕФЕКТИВНІСТЬ ЛІКУВАННЯ АРТЕРІАЛЬНОЇ ГІПЕРТЕНЗІЇ У ХВОРИХ НА ЦУКРОВИЙ ДІАБЕТ 2 ТИПУ
}

\author{
๑В. І. Вдовиченко, В. В. Кульчицький \\ Львівський національний медичний університет імені Данила Галицького
}

На теперішній час однією з найактуальніших проблем сучасної медицини є проблема перебігу та лікування цукрового діабету 2 типу (ЦД) через високу поширеність і високі рівні летальності та інвалідизації. Разом з тим доведено, що у 70-80 \% хворих на ЦД 2 типу діагностується гіпертонічна хвороба (ГХ), яка призводить до смерті у понад 50 \% пацієнтів і суттєво збільшує ризик ускладнень цукрового діабету.

Артеріальна гіпертензія (АГ) частіше виникає при першому, ніж при другому типі цукрового діабету, однак після поправки на вік виявляється, що частота ї̈ при 2 типі ЦД зростає в міру старіння. Близько 90 \% хворих, у яких АГ поєднується з діабетом, мають саме 2 тип останнього.

Лікування артеріальної гіпертензії при діабеті має велике значення для покращення прогнозу життя та профілактики ускладнень. Численні дослідження цієї проблеми, проведені зарубіжними та вітчизняними вченими, показують, що найефективнішою стратегією боротьби з АГ при ЦД 2 типу $\epsilon$ поєднання медикаментозної терапії кількома групами препаратів для зниження артеріального тиску (АТ) і модифікація способу життя. Однак і досі невирішеними залишаються проблеми вибору препаратів, які найоптимальніше знижують АТ у пацієнтів з ЦД 2 типу та ГХ.

Мета - провести аналіз ефективності медикаментозного лікування артеріальної гіпертензії у хворих із встановленим діагнозом цукрового діабету 2 типу та супутньою гіпертонічною хворобою.

Матеріал і методи. В процесі дослідження був проведений аналіз 74 історій хвороб пацієнтів з встановленим діагнозом цукрового діабету 2 типу та супутньою гіпертонічною хворобою, які перебували на стаціонарному лікуванні в ендокринологічному та терапевтичному відділеннях 4 міської клінічної лікарні міста Львова у період з 2011 по 2013 роки. 3 них чоловіків - 30, жінок 44 особи. Ефективність лікування оцінювали на підставі досягнутого цільового артеріального тиску. Згідно з Європейськими рекомендаціями із профілактики серцево-судинних захворювань ВОО3 (2012 р.), терапевтичною метою $\epsilon$ досягнення рівня систолічного артеріального тиску (САТ) <140 мм рт. ст. і діастолічного артеріального тиску (ДАТ) <80 мм рт. ст. Розрахунки здійснювали на персональному комп'ютері за допомогою табличної програми розрахунку даних Microsoft Office Excel - 2003 і програми Statistica for Windows V.6 (Stat Soft). Вираховували середні арифметичні величини (М), похибки середніх величин (m), $\sigma-$ середньоквадратичне відхилення. Статистично вірогідною вважали різницю $p<0,05$.

Результати й обговорення. В результаті аналізу історій хвороби було виявлено, що загалом із 74 досліджуваних пацієнтів цільового АТ (рівня САТ <140 мм рт. ст. і ДАТ <80 мм рт. ст.) було досягнуто у 36 осіб, що становить 48,64 \% від загальної кількості.

Становила інтерес залежність ефективності лікування АГ при ЦД 2 типу від медикаментозних засобів, які призначалися. Із 74 пацієнтів, що лікували АГ при ЦД, 39 осіб отримували монотерапію одним антигіпертензивним засобом. Цільових значень АТ досягнуто у $19(48,70 \%)$ з них. Найефективнішими препаратами для монотерапії АГ при ЦД 2 типу виявилися БРА (у $80 \%$ пацієнтів, що приймали БРА, досягнуто цільового АТ) та інгібітори АПФ (у 50 \% досягнутого цільового АТ).

Група із 35 пацієнтів приймала кілька препаратів від високого АТ. Цільових значень досягнуто у 17 (48,57 \%) чоловік. Найефективнішими комбінаціями препаратів для зниження АТ виявилися поєднання комбінації інгібіторів АПФ з сечогінними і бета-блокаторами, а також БРА з сечогінними.

Цільових значень АТ вдалося домогтися менше ніж у половини пацієнтів, які лікувалися лише у 36 із 74 (48,64 \%), що свідчить про потребу в пошуку ефективніших способів корекції артеріальної гіпертензії у хворих на ЦД 2 типу. Найкращі результати у лікуванні ГХ, поєднаної з ЦД 2 типу, дало застосування інгібіторів АПФ та блокаторів рецепторів ангіотензину, як у якості монотерапії, так і в комбінації з іншими антигіпертензивними засобами.

Висновки. Аналіз ефективності медикаментозної терапії гіпертонічної хвороби при цукровому діабеті 2 типу, проведений на основі даних історій хвороби пацієнтів, показав, що цільових значень артеріального тиску вдалося домогтися менше ніж у половини лікованих осіб. Це свідчить про потребу в пошуку способів оптимізації антигіпертензивної терапії у хворих на цукровий діабет 2 типу. Найбільшу ефективність у плані до- 
Матеріали Всеукраїнської науково-практичної конференції «Актуальні питання діагностики, лікування, рачіональної фармакотерапії, диспансеризачії та реабілітації в практичі сімейного лікаря»

сягнення цільового тиску у хворих на гіпертонічну хворобу і супутній цукровий діабет 2 типу мають препарати з групи інгібіторів АПФ та блокаторів ангіотензинових рецепторів як у якості монотерапії, так і в комбінації з іншими антигіпертензивними засобами.

Перспективи подальших досліджень. Перспективним $є$ подальше вивчення артеріальної гіпертензії у хворих на цукровий діабет 2 типу і дослідження шляхів оптимізації лікування пацієнтів з гіпертонічною хворобою і цукровим діабетом 2 типу. 